\title{
Custodial Issues Arising upon the Conversion of One Spouse to Islam
}

\author{
Mohamed Azam Mohamed Adil*
}

\section{Rights of a Non-Muslim in Child Custody Cases}

The issue is, if one of the parents of a child converts to Islam, is that parent automatically entitled to child custody over and above the non-Muslim parent? From the Islamic perspective, Muslim jurists disagree on this issue. In a hadith recorded by Abu Dawud (\#2244):

\begin{abstract}
Abdul Hamid bin Ja'far reported from his father on the authority of his grandfather Rafi' bin Sinan, that he (Rafi' bin Sinan) embraced Islam, but his wife refused to do so. So she went to the Prophet and said: "She is my daughter, and she is weaned, or almost weaned." And Rafi' said: "She is my daughter." So the Prophet told him, "Sit on this side," and told her, "Sit on that side," and then placed the girl between them. He then said to both of them. "Call her." The girl went towards her mother, but the Prophet said: "O Allah! Guide her," so she went to her father, and took her. ${ }^{1}$
\end{abstract}

In this hadith, we observe the Prophet giving the non-converted mother a chance to seek the custodial rights of her baby daughter. However, it is also apparent that the Prophet indirectly indicated his preference towards the Muslim father, by invoking the prayer "O Allah! Guide her" when the child initially inclined towards the mother. It could be inferred that this indicates the Prophet's concern for the child, were she to be brought up in an un-Islamic environment by her non-Muslim mother. Nevertheless, each parent was given an equal opportunity to a judicial hearing.

According to Shafi'i and Hanbali schools, the religion of the parent remains the primary criterion for custodial rights. The parent who seeks custody must profess the religion of Islam. Otherwise, he or she will lose custodial rights. ${ }^{2}$ This ruling was based on verse number 141 of Surah al-Nisa': "And never will Allah grant to the unbelievers a way (to triumph) over the believers." However, this verse is general ('am), not definitive on custody matters.

On the other hand, according to Hanafi and Maliki schools, adherence to Islam is not a requirement for custodial rights. Non-converting parents are therefore also entitled to custody of their children. However, the Hanafis and Malikis have laid 
down tight restrictions; non-Muslim parents are, for example, prohibited from directly influencing their children to take up un-Islamic teachings and precepts, including going to church, learning non-Islamic religious teachings, eating pork, consuming alcohol, and so forth. ${ }^{3}$

This general position of 'equal custodial rights with restrictions' is applied in several Muslim countries, including Algeria, Kuwait, Tunisia and Morocco. In these Muslim countries, the welfare of the child(ren) is the paramount criterion when determining who has the greatest right in child custody cases. However, some additional religious provisions are still imposed on non-converting parents. For example, section 62 of the Algeria Personal Status Law provides that a nonMuslim parent should bring up their child in the faith of Islam. Article 192 of the Kuwaiti Personal Status Law provides that a non-Muslim parent is entitled to the custodial right of a child only until the age of five, or when the child begins to understand about religion (and so may be influenced by other religions). Tunisia and Morocco have almost identical provisions in this regard.

\section{The Civil Court Approach}

Currently, the Civil Courts in Malaysia tend to give joint custody to both parents, even if one of the parties is a non-Muslim. In recent years, however, this general rule of thumb has not always been followed.

For example, in the recent case of Izwan@Viran v. S. Deepa,${ }^{4}$ Izwan, a father who converted to Islam and secretly converted his two children, obtained sole custodial rights from the Seremban Syariah High Court. Shortly before, however, the Civil Court had already granted custody to the mother. The case was therefore brought to the Court of Appeal, which decided that the Civil Court had the power and jurisdiction to handle the case, despite there being a Muslim involved. The Court of Appeal therefore upheld the decision of the High Court and granted Deepa custody of her two children.

However, this decision by the Court of Appeal was later overturned at the Federal Court by a panel of five judges. The court awarded the boy ( 8 years old) to the father (Izwan) and the girl (11 years old) to the mother (Deepa). This decision was made after the two children had been interviewed in the court chambers and asked about their preferences. It was also decided that, if a marriage had been originally registered under the Law Reform (Marriage and Divorce) Act 1976, matters of dissolution, child custody and other related issues upon divorce should fall under the purview of the Civil Courts-despite one of the parties converting to Islam. Consequently, Muslim converts cannot seek relief from the Syariah Court if his/her original marriage was registered under Civil law. 
In another case, that of Sharmala Sathiyaseelan v. Dr. Jeyaganesh $C$. Mogarajah \& Anor, ${ }^{5}$ Justice Faiza Thamby Chik gave joint legal custody to both parents but actual custody (i.e. day-to-day care) to the mother. The court said that the legal joint custody granted to both parents meant that the latter would have to agree on issues concerning the children, such as education, choice of religion and property. This was in accordance with section 5 of the Guardianship of Infants Act 1961. However, the judge enforced a caveat that the children were mualaf (Muslim converts) and that the mother would lose the right to actual custody if there were reasonable grounds for believing that she would negatively influence the children's Islamic religious beliefs (for example, by instructing the children in religions other than Islam or making them eat pork).

In another case, Muhammad Riduan Abdullah (Pathmanathan) v. Indira Gandhi, ${ }^{6}$ both parties had entered into a civil marriage under the Law Reform (Marriage and Divorce) Act 1976. After being blessed with three children, Pathmanathan converted to Islam and changed his name to Muhammad Riduan. He also converted his three children, without his wife's consent. He later filed for custodial right of the children at the Ipoh Syariah High Court, which granted his application. Indira, however, later filed a judicial review at the Ipoh High Court, seeking to nullify the conversion of her three children. The Ipoh High Court granted her application. Disappointed with this decision, Muhammad Riduan went to the Court of Appeal; in a 2-1 majority, the Court of Appeal granted his application on the grounds that only a Syariah Court has jurisdiction over an individual's religion and matters relating to conversion to Islam. In this case, therefore, the Court of Appeal took the position that the Civil Courts have no jurisdiction over matters relating to Islamic law, including the determination of the religion of a minor.

From these examples, it is clear that, in cases where a father or mother embraces Islam and later converts their child(ren) to Islam before a child custody decision has been made by the court, problems lie ahead. It would be better if the determination of a child's religion takes into account who is entitled to take custody of the child. It requires cooperation by all parties, especially parents, guardians and the authorities. What is important is that the welfare of the child comes above all else.

Finally, it is argued here that the problems pertaining to interfaith child custody could be solved if parties whose marriage was registered under the Civil law resolve their marriage at the Special Court/Civil Court. This is in line with the move announced by Nancy Shukri, Minister in the Prime Minister's Department, that the government will be proposing amendments to Sections 51 of the 1976 Act and 46(1) of the Islamic Family Law Act 1984 in the next Parliament seating. This could put an end to the tussle between Muslim and non-Muslim parties in 
matters relating to dissolution of marriage, custodial rights and other interfaithrelated matters.

\section{Notes}

* Mohamed Azam Mohamed Adil is the Deputy CEO, International Institute of Advanced Islamic Studies (IAIS) Malaysia (Email: mazamadil@iais.org.my).

1. Abu Dawud Sulaiman Ash'ath, Translated by Nasiruddin al-Khattab (2008). Sunan Abu Dawud: English Translation of Sunan Abu Dawud. Riyadh: Darussalam. Hadith \#2244.

2. Abdul Rahman al-Jaziri (1986), Kitabul Fiqh ala al-Mazhabal-Arba'ah, Vol. 4, Darul Fikr, Beirut, p. 597.

3. Supra, p. 598.

4. [2015] 3 MLJ 209.

5. [2011] 1 CLJ 568 FC, [2004] 1 CLJ 505.

6. (2015) Civil Appeal No. A-02-1826-08/2013 